\title{
Language planning in the Low Countries (1996-2005): The Dutch Language Union ${ }^{1}$
}

\author{
Marc van Oostendorp
}

\section{Introduction}

Dutch is a West-Germanic language spoken by approximately 22 million people worldwide. It is the official language of Surinam, the Netherlands Antilles and Aruba - all of these are former colonies of The Netherlands - but most speakers (app. 21 million) live in the Netherlands or Belgium. ${ }^{2}$ In 1980, these two countries established the Nederlandse Taalunie ('Dutch Language Union', henceforth $D L U$ ), as a common governmental body which is responsible for the policies of both countries with respect to the Dutch language, language education and literature. Surinam became an associated member of the DLU in 2004. This article gives a critical overview of the activities of DLU, concentrating on the most recent decade 1996-2005, the period of EU expansion, and disregarding activities concerning literature and (mostly) language education as well as the position of Surinam, since none of these are central to our present concerns.

As we will observe, 'international' developments, i.e. developments outside of the Dutchspeaking area, such as within the European Union, have not played an important role in discussions on language policy within our timeframe. To the contrary, it looks as if public interest has been much more concerned with internal debates. One might speculate that there is a correlation with a more general lack of interest in 'European' affairs. The population of the Netherlands voted against a European Constitution in a 2005 referendum - there was no similar referendum in Belgium.

There are several reasons why an overview of language planning policies within the Netherlands is of interest. First, since almost all policies in the Netherlands and Flanders concerning language have been coordinated by the DLU, studying language policies in the Low Countries to all intents and purposes equals studying the workings of the DLU: it is hard to think of somebody who is interested in issues of language policy in the Low Countries and who has not been engaged with the DLU in one way or another. Secondly, the DLU seems to be unique in the world; international governmental bodies to which all linguistic policies of several nation-states have been delegated do not exist elsewhere, to the best of my knowledge. They certainly do not exist in Europe. Thirdly, the intensive collaboration between these two EU member states - who have delegated basically all their policies on this terrain to this common body - may be seen as a model for a more closely knit European organisation. Finally, no scholarly literature exists on these issues, beyond some works which have been published under auspices of the DLU (e.g. De Caluwe et al. 2002) and work on DLU in a previous period (e.g. Goyvaert 1982, Willemyns 1984a, 1984b).

Like all politics, language policies are the result of tension. In this article, we will see that one tension underlying the work of the DLU in the era described here has been the one between the opinions of linguistic scholars (sociolinguists, computational linguists) on the one hand and those of linguistic 'laymen' such as politicians, civil servants and the general public on the other hand. DLU has been active in trying to bridge the tension, applying insights from linguists where-ever this was possible. However, it has not always been very successful in doing this, and I analyse the potential causes for the problems.

After giving some relevant background information on the history and organisation of DLU as well as on some political and cultural differences between the Netherlands and Flanders in section 2, I discuss issues in the 'corpus planning' policies of DLU - i.e. those issues

1 I would like to thank Ulrich Ammon, Leonie Cornips and an anonymous reviewer for discussion.

2 These numbers are based on information from the website of the Dutch Language Union: http:/ / taalunieversum.org/taal/vragen/antwoord/4/ (last checked, February 2007). 
concerning the language itself - in section 3 and the 'status planning' policies - those concerning the status and prestige of the language within Dutch and Flemish territory as well as in the rest of the world in section 4 . The last section is devoted to a conclusion.

\section{Background information}

In 1980, the governments of the Kingdom of the Netherlands and the Kingdom of Belgium signed an agreement to found the DLU; this agreement was ratified by the Dutch Parliament as well as the Flemish Council. The general goal of the DLU was expressed as follows: ${ }^{3}$

(1) The DLU has as its goal the integration of the Netherlands and the Dutchspeaking community in Belgium in the area of Dutch language and literature in its broadest sense. ${ }^{4}$

More specifically, the agreement mentioned four main goals:
a. collective development of the Dutch language;
b. collective promotion of knowledge and well-considered use of the Dutch language;
c. collective promotion of literature in Dutch;
d. collective promotion of the study and distribution of the Dutch language and literature abroad. ${ }^{5}$

In order to achieve these goals, a number of official bodies has been established. Central in this is the Committee of Ministers, consisting of the responsible members of the Dutch and Flemish government. The policy is monitored by an 'Interparliamentary Committee' of 22 Dutch and Flemish MPs; a result of this is that the policy of the DLU is not (necessarily) directly controlled by the complete parliaments of the member countries. The Committee of Ministers is advised by the twelve members of the Raad voor de Nederlandse Taal en Letterkunde ('Dutch Language and Literature Council'). These members are often senior scholars in the relevant disciplines. Finally, the preparation and implementation of the policies set out by the Committee of Ministers is executed by the staff of the Secretariat General. According to the DLU website, this staff currently contains approximately 25 employees.

It seems to be an implicit policy that the employees of the DLU are recruited among Dutch and Flemish candidates in a roughly equal proportion; the position of Secretary General has so far always alternated between Dutch and Flemish civil servants.

The function is a rather important one in the present context, since the Secretary General often represents DLU, and therefore the Dutch and Flemish government in public debates in the media and elsewhere; furthermore, he or she probably has some influence on the day to day

3 'Verdrag tussen het Koninkrijk België en het Koninkrijk der Nederlanden inzake de Nederlandse Taalunie, ondertekend te Brussel op 9 september 1980', available at http:/ / taalunieversum.org/taalunie/verdrag_inzake_de_nederlandse taalunie/; checked 21.3.2007

4 'De Taalunie heeft tot doel de integratie van Nederland en de Nederlandse gemeenschap in België op het gebied van de Nederlandse taal en letteren in de ruimste zin.' All translations are my own, except otherwise indicated.

5 'a. de gemeenschappelijke ontwikkeling van de Nederlandse taal;

b. de gemeenschappelijke bevordering van de kennis en het verantwoorde gebruik van de Nederlandse taal;

c. de gemeenschappelijke bevordering van de Nederlandse letteren;

d. de gemeenschappelijke bevordering van de studie en verspreiding van de Nederlandse taal en letteren in het buitenland.' 
decision making. In the period 1996-2005, DLU has had three different Secretaries General: ${ }^{6}$ Mrs. Greetje van den Bergh (until December 1997) from the Netherlands, who was educated as a translator and has occupied various official positions in the Dutch and Flemish academic and cultural world after having stepped down as an SG; Mr. Koen Jaspaert (from March 1998October 2004), a Flemish linguist who occupied academic positions (professorships) at Dutch and Flemish universities both before and after his assignment as an SG; and Mrs. Linde van den Bosch, a Dutch linguist at the MA level who had previously worked for Cito, a Dutch agency occupied in preparing among other things official tests and exams for primary and secondary education in the Netherlands.

The backgrounds of these SGs seems relevant: the three main areas of interest of the DLU (literature, language, language education) were covered by the three SGs of the past decade. For our purposes, it is of considerable interest that Dr. Jaspaert, who served the longest term within our timeframe, is a published linguist, who mentions 'sociolinguistics', 'language teaching', 'minority languages' and 'language policy' as his areas of professional interest on his website. ${ }^{7}$ It will be shown in the following sections that these interests matched several prominent aspects of the DLU's policies quite well.

International intergovernmental institutions within Europe always have to deal with cultural differences as well. In order to understand the delicate position of the DLU better, it is therefore relevant to study some of the differences between the Netherlands and Flanders with respect to language issues. Van Oostendorp (2007) gives an overview, which we will summarise here.

In the first place, we may observe that so far, the Dutch language has a more prominent and explicit role in the Belgian Constitution than in its Netherlands counterpart (both countries are constitutional monarchies). In the Belgian Constitution, part of the country is officially designated as Dutch-speaking. The Dutch Constitution does not mention the status of Dutch at all, and so far, attempts to formalise the status of Dutch in the Constitution have failed in parliament, in spite of its rather weak formulation. ${ }^{8}$

This difference is certainly related to the different linguistic situation in the two countries. Belgium is a trilingual state (Dutch, French, German) in which at least Dutch and French have been in competition for a long time. On the other hand, even though the Netherlands in some respects is a bilingual nation, one of those two languages, Frisian, does not play a real role on the national stage; its official use is limited to the province of Frisia. Therefore, the role of Dutch in national public life is uncontested and has been so for a long time, whereas the situation is different in Belgium.

The status of minority languages in general is a difference between the two countries. The government of the Netherlands signed the European Charter for Regional Languages or Languages of Minorities in 1992 (Leerssen and Heumakers 2002; see also section 5). The Belgian government on the other hand, has never signed the European Charter, possibly because of expected problems with French speakers in 'Dutch-speaking' areas and Dutch speakers within 'French-speaking' areas.

All in all, the main difference between the two countries thus seems to be that the Dutchspeaking community is dealing with an internationally important language. Another important factor, which becomes less apparent from the overview in Van Oostendorp (but see

6 We disregard Mrs. Joep Baartmans, a Dutch civil servant (currently mayor of the Dutch town of Vught) who was an 'interim' SG in the period between January-March 1998.

7 http:/ / www.kuleuven.ac.be/cv/u0015206e.htm; checked 21.3.2007

8One proposal ('Voorstel tot wijziging van grondwetsartikel 22a' by parliamentarians Alis Koekkoek (CDA) and Eimert van Middelkoop (GPV), October 1995.) stated: 'the promotion of the use of the Dutch language is an object of attention for the government' (De bevordering van het gebruik van de Nederlandse taal is voorwerp van zorg van de overheid), hardly a revolutionary statement. Instead, a regular law was adopted, formalising the use of Dutch as a language of government communication (Beheydt 1997). It should be noted that the new Dutch government announced in February 2007 that it is planning to forward a new proposal. 
Van De Velde 1996 and references cited there) is that 'Standard Dutch' for a long time was considered to be closely related to indigenous varieties of the Netherlands, not of Belgium. In practice, Dutch speakers of Belgium seem to be living in a situation of diglossia, with their dialect and a standard language which is at quite some linguistic difference. This situation seems to be changing nowadays, but it may still hold true to some degree.

Together, these factors are assumed to result in a situation in which language policies are considered much less important by Netherlands speakers of Dutch: they see no immanent threat from another language and generally have the feeling that they speak their own language rather well (Smakman 2006). Flemish speakers, on the other hand, demand a stricter language policy. Given these differences, it seems a natural conclusion that Flemish participants will have a different expectation of the DLU than their Dutch counterparts. On the other hand, the differences between the two cultures also should not be overestimated. Van Oostendorp (2007) shows that the arguments which are put forward in debates about the use of Dutch in Europe are not significantly different between Dutch and Flemish highbrow newspapers (NRC Handelsblad and De Standaard respectively), as compared to their French counterpart Le Monde. A clear difference was visible in the way the Dutch and Flemish newspapers discussed issues of (Dutch) spelling reform: the Dutch newspaper was much more critical of the DLU reform proposals than the Flemish newspapers; we will return to this in section 5. However, in informal internet discussions also these differences seemed to all but disappear: both Dutch and Flemish contributors could be either critical of the reform or supporting it. This difference is probably to be explained by the fact that the editors of NRC Handelsblad decided to support an alternative plan for the spelling, whereas the editors of De Standaard did not. This in itself therefore does not necessarily reflect a difference in national attitude, as the data from internet discussions show.

\section{Official policy: corpus}

In order to structure our description of the policies of DLU, we find it useful to draw the usual distinction between corpus planning and status planning policies (Kloss 1969, Cobarrubias and Fishman 1983, Haugen 1990). DLU is engaged in numerous activities in both fields (Willemyns 1990). The distinction is obviously not always clear: e.g. activities concerning automatic translation serve a 'corpus function' since they involve setting up electronic dictionaries and implementing grammars, but at the same time involve activities of status planning, trying to make commercial partners interested in applying their technology to your own language. Yet in most cases, there is a clear emphasis on one aspect or the other. We will see that status planning activities of the DLU often have an implicit European focus: whether they are dealing with language variation within the language area or the international position of Dutch, they are very often based on European agreements and consensus. It is only natural that corpus planning activities have a more local bias: work on dictionaries, etc., by necessity is less international in scope. In the period, described here, the focus has been mostly on the corpus planning; this is in line with Willemyns (1997), who showed that although the initial emphasis in the DLY Treaty seemed to have been on status planning, the actual focus of activities soon moved to corpus planning.

It cannot be our goal to cover all activities of the DLU in this article; we have to focus on some of them. Yet it is our attention to give at least a representative overview. Within the realm of corpus planning policies, these concern (1) working on terminology databases and dictionaries, (2) applying language and speech technology, (3) setting up a database of language advice, (4) working on guidelines for the 'official' spelling of Dutch. These activities are presented in this order in the following sections. This order is not random: it reflects the relative amount of interest each of these topics is likely to induce within the general public in the Netherlands and Flanders. We will see that this is indeed, at least roughly, the case. In 
particular, DLU is most known in the Dutch-speaking world as a spelling regulating organisation; as such, it has suffered from quite some controversy over the decade which is described in this article.

\subsection{Terminological and lexicographic activities}

The production of dictionaries has never been an explicit goal for the DLU; it thus differs in this respect from e.g. the Académie Française and some other language organisations within Europe. One reason for this is that several commercial and non-commercial parties were already successfully involved in this business when the DLU was established.

The main non-profit (academic) party is the Instituut voor Nederlandse Lexicologie ('Institute for Dutch Lexicology', INL) in Leiden, an academic institute responsible for several prestigious dictionaries. ${ }^{9}$ Most of these are historical in focus, such as dictionaries for Old Dutch, Early Middle Dutch and Middle Dutch. The most well-known dictionary is the Woordenboek der Nederlandsche Taal ('Dictionary of the Dutch Language', WNT), a 43 volume collection comparable to the Oxford English Dictionary (OED) by James Murray or the Deutsches Wörterbuch by Jacob and Wilhelm Grimm. Work on WNT started already in 1851, but it was completed only in 1998 (Van der Horst 1999). This completion was a rather big public event, and got the attention of most news media, who like to mention that WNT is "the world's largest dictionary", bigger than any English, French or German competitor ${ }^{10}$.

The DLU has been one of the chief sponsors of INL, and hence of WNT and the other dictionaries. It should be noted, however, that WNT does not seem to play an important role in public awareness about dictionaries. The reasons for this may be that the dictionary is too voluminous. For a long time, it was basically impossible for an individual to own a copy of this dictionary, although a paperback version appeared between 1993 and 2001, and a cd-rom version in 1995; these were still rather expensive however, and WNT only really became available for a general public in January 2007, when a (free) online version appeared. ${ }^{11}$ Another reason why WNT does not seem to have the authoritative function of $O E D$ or Deutsches Wörterbuch, is because a commercial product has already usurped that role: Van Dale Groot Woordenboek der Nederlandse Taal ('Van Dale Great Dictionary of the Dutch Language', named after one of its first editors, Johan Hendrik van Dale). This dictionary is used, for instance, in a televised collective Dutch and Flemish spelling bee; accepted by national Scrabble player's organisations as they key reference; etc. The fact that this commercial product is the de facto standard is probably the reason why lexicographic work was never high on the DLU agenda. On the other hand, WNT serves a different, more scholarly function: it contains more words - the 2005 edition of Van Dale counted 265,000 lemmas ${ }^{12}$, whereas WNT has over $400,000^{13}$ - and each of the lemma's is substantially longer. Furthermore, WNT covers the period 1500-1976, whereas Van Dale describes 'current Dutch', looking back approximately 150 years. ${ }^{14}$

9 INL is engaged in several other activities, such as building up text corpora and word lists and sponsoring lexicological and lexicographic scholarly research; we will disregard these. However, INL has also been (partly) responsible for the production of the offi ial standard of Dutch orthography, to which we will return in section 3.4.

10 http:/ /taalunieversum.org/taalpeil/wat is het grootste woordenboek ter wereld.html; checked 17.3. 2007

11 On Thursday February 8, 2007, the website of newspaper NRC Handelsblad noted in the fis $\mathrm{t} 10$ days of its existence, over 22,000 users had registered for the WNT website. The cd-rom had been sold in a quantity of at most 1500 copies (http: / weblogs.nrc.nl/weblog/woordhoek/2007/02/08/grote-belangstelling-iwnt/; checked 17.3.2007).

$12 \mathrm{http://www.vandale.nl/overvandale/overvandale/;} \mathrm{checked} \mathrm{21.3.2007}$

13 http:// www.inl.nl/index.php?option=com_content\&task=view\&id=222\&Itemid=244; checked 21.3.2007

14 Subsidized by the DLU, INL is also engaged in setting up a scholarly online dictionary of current Dutch, which will cover the period 1976-2019. 
Next to scholarly lexicography, DLU also sponsors terminological projects, which are coordinated by a special Commissie Terminologie ('Terminological Committee'). Members of this committee include specialists in translation services, medical communication, normalisation and linguistics. The committee publishes a website NedTerm featuring information on terminological tools, terminological publications ans terminological organisations. The most important job of the Terminological Committee, however, is to subsidize projects, in particular regarding electronic tools for terminological work. One possible application for this is language technology (cf. section 3.2).

The DLU thus is not directly engaged in lexicographic and terminological work itself, but it subsidizes and facilitates studies in this area. Since these are activities which would not usually be undertaken by individuals or companies, it seems a logical consequence that a governmental body steps in, in case it is agreed upon that such activities are necessary. International cooperation between Dutch-speaking countries within Europe, such as it is taking shape within the DLU, also might be classified a positive development. ${ }^{15}$ The beneficiaries of these activities primary seem to be scholars (not just in linguistics, but also in many historical disciplines in the case of lexicography) and professionals (in all kinds of disciplines in the case of terminological projects). The work does not seem extremely wellknown among the general public, and it is not very controversial.

\subsection{Language and speech technology}

The 1980 Agreement did not explicitly mention language and speech technology as a goal of the DLU. The reasons for these are obvious: computer use of natural language at the time was not very high on the agenda of politicians and officers. Yet in a DLU report, Daelemans and Strik (2002:7) state that "in order to guarantee the status of Dutch in a quickly evolving multilingual information society, it is necessary that ICT applications are developed quickly and adequately in a Dutch version. A precondition is the availability of a digital infrastructure, consisting of high quality data (lexicons, corpora), and software modules which can be used in the development of applications. At the moment some of the necessary basic materials for Dutch are seriously missing. " The argument thus is that a (standard) language will only be able to acquire enough 'status' if it can be used in electronic environments, e.g. if it can be used in complex document databases. The EU plays an important role in this argumentation, since the bodies of the EU are an important international organisation promoting the use of language technology to serve its complex task of keeping up multilingualism.

Parties which want to promote the Dutch language should therefore make sure that such infrastructure is available. The field already sees various organisations working in this area, both commercial (software companies) and academically (computer science, speech technology, computational linguistics, etc.), but one could argue that it would be a waste of resources if each of these has to set up the 'basic infrastructure' in their own right. Reports such as Daelemans and Strik (2002) have been a signal for the DLU to take the task of building a 'digital infrastructure' seriously (Nederlandse Taalunie 2003).

In actual practice, this infrastructure seems to incorporate a number of heterogeneous things, such as making available on line a prestigious reference grammar for human readers ${ }^{16}$ and coordinating academic and commercial activities in the area of speech technology. ${ }^{17}$ Here we concentrate on the latter, more technical, activities, we return to the former in section 4.4. The main result of the proposals of reports like Daelemans and Strik (2002) was the

15 The DLU has also subsidized a number of translation dictionaries. Cf.

http: / / taalunieversum.org/taal/ nederlands / (checked 21.3.2007) for an overview.

16 http://www.ru.nl/e-ans/ (checked 21.3.2007)

17 http://taalunieversum.org/taal/technologie/ beleid.php (checked 21.3.2007) 
establishment of a 'research and encouragement program' called STEVIN. The name is an acronym for Spraak- en Taaltechnologische Voorzieningen in het Nederlands ('Facilities for Speech and Language Technology in Dutch') and furthermore refers to Simon Stevin (1548-1620), a famous Flemish mathematician and defender of the Dutch language. The programme works on a budget of $€ 11.4$ million for the 2004-2010 period and is financed by the DLU, the Dutch and Flemish ministries of Economic Affairs and of Education and the Dutch and Belgian Research Foundations. Currently, a number of research and development projects is running, regarding a variety of topics, such as devising tools for phoneme transcriptions for Dutch names, for large scale automatic syntactic tagging, and for checking use of jargon in texts by the Dutch government designed for a general public.

A slightly different activity sponsored by the DLU is the so-called TST Centrale ('Language and Speech Technology Central'), which is based at INL (see section 3.1) and aims to maintain a number of resources (corpora, lexicons, etc.) which have usually been the result of earlier research. In earlier times, such resources were usually left on their own (and sometimes lost) after a research project was finished. The Central tries to keep them available and readable with the latest technology. Already, an impressive number of materials is available through the Central's website, ${ }^{18}$ such as the WNT (section 3.1), but also the Corpus Oudnederlands, a comprehensive corpus of Old Dutch texts, the Corpus Gesproken Nederlands, a corpus of several million words of Spoken Dutch, and the two official Word Lists of the Dutch language (cf. section 3.4).

It should be noted that so far very few purely commercial products have emerged as a result of these activities; target groups mentioned by STEVIN projects very often involve state organisations such as the court of justice or state departments. ${ }^{19}$ The main benificiaries of these activities therefore so far seem to be academics and companies working in language and speech technologies. There is not a lot of public awareness of these activities, and they also do not seem very controversial.

\subsection{Advice on language usage}

A third type of activity concerns so-called taaladvies ('advice on language usage'): a database of questions and answers concerning the 'correct' usage of the Dutch language, which is available on a separate website Taaladvies.net. ${ }^{20}$

Setting up this database clearly corresponds to one of the chief official goals of the DLU, viz. the one mentioned in (2a): 'collective promotion of [...] well-considered use of the Dutch language'. On the Taaladvies website, we find the following explanation for the establishment of the website:

(3) Taaladvies counters the need of many users of Dutch - native speakers and people who have learned Dutch as a second or foreign language - for reliable and trustworthy advice on language use. The DLU wants to make such advice available to a large and broad audience, and to promote in this way the usage of correct Dutch. Because of the internet we can answer the demand for expert advice more quickly and more easily. ${ }^{21}$

18 http:/ / www.tst.inl.nl/ (checked 21.3.2007)

19 See, however, Rietveld and Solte (2005) who explicitly argue that Language and Speech Technology Products should and can be produced for people with a 'communicative handicap', either cognitive (aphasia, dyslexia) or physical (blindness, deafness, stuttering, etc.) No concrete action has been taken in this regard, as far as I can see.

20 http: / / taaladvies.net/

21 'Taaladvies voorziet in de behoefte van veel gebruikers van het Nederlands - moedertaalsprekers en mensen die het Nederlands als tweede of als vreemde taal geleerd hebben - aan verantwoorde en betrouwbare taaladviezen. De Nederlandse Taalunie wil zulke adviezen kosteloos aan een zo groot en zo breed mogelijk publiek beschikbaar stellen en daarmee het gebruik van goed Nederlands bevorderen. Dankzij het internet kan 
A number of problems arise, however. First, it is not so clear what exactly constitutes 'correct Dutch' and who is going to be expert enough to decide about these matters. Secondly, it is also not so clear that state bodies can successfully 'promote' whatever norms it chooses to adopt (cf. Milroy 1990).

Interestingly, the highest official within the DLU at the time when Taaladvies was put online, dr. Koen Jaspaert (cf. section 2) was very well aware of these problems and has published on them (e.g. Jaspaert 1986). In the fall of 2003, Jaspaert published an interesting article in a Dutch national newspaper (Jaspaert 2003), mentioning two reasons why state bodies should exercise restraint in matters of language prescription. First, 'language evolution does not really care about any form of guidance'; and, secondly,

'it is dangerous for a government to emphasize correctness in a language which people in several countries and regions all consider to be their own. [...] Very often, no linguistic argument can be given to choose one expression rather than another one. In many cases, we see that whoever makes such a judgement, and gives suggestions about it, bases himself on the properties of speakers who use a certain variety. This is very dangerous.

[...] What happens if we promote the language of the urban elites in Randstad ${ }^{22}$ to the 'correct' standard language and brand the Flemish, the Surinamese, people outside of Randstad, young people, immigrants, inhabitants of working-class districts, etc., as users of a corrupted form of Dutch?

My prediction is that such groups will very rapidly be alienated from that Dutch language. This alienation is the biggest threat to that Dutch language, it seems to me. As long as 22 million speakers of Dutch feel that they have their own language, with which they can do many more things than with that foreign English, the Dutch language has little to fear. ${ }^{23}$

The quotation is very interesting for many reasons. For instance, it identifies the most likely source of correctness judgements within the Dutch speaking world: the urban elites in the Randstad area. It also provides an original argument against correctness: this would 'alienate'

sneller en gemakkelijker voldaan worden aan de vraag naar deskundig advies.Taaladvies voorziet in de behoefte van veel gebruikers van het Nederlands - moedertaalsprekers en mensen die het Nederlands als tweede of als vreemde taal geleerd hebben - aan verantwoorde en betrouwbare taaladviezen. De Nederlandse Taalunie wil zulke adviezen kosteloos aan een zo groot en zo breed mogelijk publiek beschikbaar stellen en daarmee het gebruik van goed Nederlands bevorderen. Dankzij het internet kan sneller en gemakkelijker voldaan worden aan de vraag naar deskundig advies.'

22 Randstad ('Border city') is a popular name for a region in the Netherlands which has been the cultural and economic center of the country for a long time: it contains the cities of Amsterdam, Rotterdam, The Hague and Utrecht as well as a number of smaller cities such as Leiden, Dordrecht and Haarlem.

23 Voor een taal die in verschillende landen en gebieden als eigen ervaren wordt, is het zeer gevaarlijk om vanuit de overheid de correctheid te sterk te benadrukken. [...] Heel vaak is er geen enkel taalkundig argument te geven waarom de ene constructie wordt verkozen boven de andere. In de praktijk zie je dat wie zich uitspreekt voor een dergelijk oordeel en daartoe ook suggesties doet, zich meestal baseert op de kenmerken van de sprekers die een bepaalde variant aandragen. En daarin schuilt nou net het gevaar.

[...] Wat gebeurt er als men het Nederlands van de Randstedelijke elite uitroept tot correcte standaardtaal en Vlamingen, Surinamers, niet-Randstedelingen, jongeren, allochtonen, volksbuurtbewoners, et cetera bestempelt als gebruikers van een gecorrumpeerd Nederlands?

Mijn voorspelling is dat die groepen in sneltreinvaart zullen vervreemden van dat Nederlands. In deze tijd lijkt deze vervreemding mij nu juist het grootste gevaar dat het Nederlands bedreigt. Zolang 22 miljoen

Nederlandssprekenden vinden dat ze een eigen taal hebben waarmee ze zoveel meer kunnen doen dan met dat vreemde Engels, heeft het Nederlands weinig te vrezen. 
non-standard speakers from 'their' language, and lead them into the arms of English. Yet the most interesting aspect of this quotation is that it is coming from the highest official within an organisation that is at the same time involved in 'promoting correctness'. Jaspaert (2003) is aware of the paradox and argues that speakers sometimes feel insecure about the standard language, choices need to be made and in these cases they need advice, and an 'informed choice of language usage'. Next to diversity, unity is needed so that 'everybody can recognize everybody else within the Dutch speaking language area as users of a common language'. It does not become clear, however, on which criteria the choices are made which would help the language users in their 'insecurity', or why making choices like this would be necessary for the recognition of other speakers: the DLU could also have chosen to promote knowledge of the different varieties, which might lead to the same result.

These questions are not answered on the Taaladvies website itself either. ${ }^{24}$ It explains that a group of scholars and 'language advisors' from the Netherlands and Flanders are responsible for the advice and that this advice does not have the status of a law. It is not explained what criteria have been used, but consultation of some of the advices given suggests that the main criterion is what existing sources (style guides, prescriptive grammars) on the issue say. It is not clear how this would not alienate non-Randstad speakers. As a matter of fact, the whole arbitrariness of language advice, which was eloquently worded in Jaspaert (2003) is not mentioned.

We see a clash here between 'popular demand' and the expert's opinion. The general public is supposed to feel insecure and to ask for 'expert advice'. The expert, on the other hand, knows that most choices are arbitrary and/ or based on sociological grounds, and is therefore hesitant to provide such advice. This hesitation can in turn be seen as a sign of weakness Jaspaert (2003) is a reaction to allegations that the DLU would be willing to support 'changes' in the standard language. It is unknown how big the 'general population' is that really needs the expert advice. We do not know how many people use Taaladvies at present. The latest report which is available is Nederlandse Taalunie (2006). It mentions that 14,237 questions were asked during 2005, which boils down to 40 every day. It is not clear what we should compare these numbers to exactly, but the website of the private association for language lovers Onze Taal got approximately 10,000 questions in the same period.

\subsection{Orthography}

We see a much bigger clash between the expert's opinion and public expectations in the case of spelling. Orthography is governed by law in the Netherlands and Flanders: the state (or the DLU) determines an official spelling, which should be obeyed by civil servants and the schools, although there are no sanctions against 'trespassers'.

Spelling is probably only a minor task for the Secretariat General of the DLU, but it determines the public image of this organisation to a large extent. It looks as if for many people, the spelling - and in particular promotion of undesirable changes of the spelling - is the main occupation of the DLU.

Formally, the official spelling is described in the Word List of the Dutch Language (Woordenlijst Nederlandse Taal), commonly known as the Little Green Book (Groene Boekje). This book consists of two parts, an introduction describing the general rules and the actual word list, containing approximately 100,000 words. The book is produced by INL. In 1994, the DLU decided that the spelling rules would be fixed in the 1995 edition; after this, a new edition of the Word List would be published every 10 years, but the changes would only involve changes in the list of words itself: neologisms would be added, whereas words which got out of use would be erased.

The period described here has seen discussions regarding two editions, one appearing in 1995

$24 \mathrm{http}: / /$ taaladvies.net/taal/advies/verantwoording/ 
and one appearing in $2005 .^{25}$ The appearance of the 1995 edition created some turmoil which lasted well into 1996 - the official rules became effective as of the latter year. I think it is fair to say that three criticisms prevailed. First, people found typos and other errors in the word list. Secondly, it was noted that there were differences between the Word List and the latest edition of Van Dale, involving between 100 and 200 words - this seems like a minor detail, but the issue was even raised in Dutch parliament. Thirdly, and most importantly, critics expressed their anger at some of the new rules, in particular those concerning the spelling of compounds. (See Wilterdink 2004 for a sociological-historical approach to this first spelling debate.)

One important opponent of the spelling was the association Onze Taal ('Our Language'), an association of language enthousiasts counting approximately 40,000 members and publishing a monthly magazine on the Dutch language. ${ }^{26}$ The association's journal published many articles exposing the reader's griefs against the spelling reform. Yet in spite of this debate, eventually almost all publishers and media, and also the editors of Onze Taal, decided to follow the new rules in 1996, and after this the debate about spelling soon disappeared, only to reappear in 2005, at the introduction of the new edition of the Word List.

At this occasion, it became clear that one (minor) rule had changed, in spite of earlier promises to the contrary. As a matter of fact, the change involves only an exception of the general rule on spelling of compounds, which was declared to be no longer exceptional, hence to fall under the general rule. Further, some words were spelled differently because the old rules had been applied in a slightly different way. Somehow, these changes caused a lot of indignation, at least some of it going back to the problems which arose in 1995. In the fall of 2005, all Dutch national newspapers except for one ${ }^{27}$ as well as all news magazines and several tv programmes declared that they would 'boycott' the new spelling rules. Flemish media on the other hand all defended or at least followed the new rules.

In several cases, the criticism was directly aimed at the DLU. In this particular case, an official Spelling Committee had been established, consisting of three Dutch and three Flemish professors of Dutch Linguistics. One prominent Dutch journalist on language issues ananlysed the problems as follows (Sanders 2005):

[The Spelling Committee of the DLU] consists of a number of clever linguists. When linguists decide, they take regularities in a group of words into account. [...] From a scholarly point of view, they are absolutely right, but I think the Spelling Committee disregards the 'average' language user, who does not look at groups of words, but at individual words. Not everybody knows what a 'free compound' is, for instance [...] and that makes it more difficult to follow the rules and argumentations of the Spelling Committee. I think one should not just have clever linguists in such a committee, but primary school teachers as well, who have to be able to explain it. ${ }^{28}$

25 The Dutch edition of Wikipedia contains an excellent article on the history of Dutch spelling: http:/ / nl.wikipedia.org/wiki/Geschiedenis_van_de_Nederlandse_spelling.

26 For the sake of transparancy, it should be mentioned that the author of this article has been employed by Onze Taal between 1997 and 2006. It should also be mentioned that I have published various articles in Dutch newspapers arguing against having orthographic rules imposed by law.

27 The one exception was the right-wing newspaper De Telegraaf.

28Die bestaat uit een aantal slimme taalkundigen. Taalkundigen kijken bij hun beslissingen naar regelmatigheden in grote groepen woorden. [...] Wetenschappelijk gezien hebben zij daar volkomen gelijk in, maar ik denk dat de spellingcommissie te weinig oog heeft voor de 'gewone' taalgebruiker, die niet naar grote groepen woorden maar juist naar individuele woorden kijkt. Lang niet iedereen weet bijvoorbeeld wat een ongelede samenstelling is [...], en dat maakt het moeilijk om de regels en redeneringen van de spellingcommissie te volgen. Volgens mij moet je niet alleen slimme taalkundigen in zo'n commissie zetten, maar bijvoorbeeld ook onderwijzers, die het moeten kunnen uitleggen. 
I believe that this expressed (a moderate version of) a common opinion at the time: the members of the Spelling Committee were too far removed from 'reality'. The weekly Elsevier claimed, in a more aggressive tone:

Linguists are the mathematicians of language. Don't ask these mathematical linguists for love of a word or fascination for etymology (the origin of a word). Language has to be renewed, spelling has to be renewed: and all of this at the service of the desired uniformity. ${ }^{29}$

Interestingly, the boycotting parties would decide towards the end of 2005 to cooperate with the association Onze Taal. This association would publish its own spelling guide in 2006 (called The Little White Book 'Het Witte Boekje'). It can't be said that this spelling guide is very radical in any respect, and it follows the official Word List in many of its details. However, apparently the linguists of Onze Taal - who work as language advisors, cf. Section 3.3. apparently seemed less 'clever' and more 'realistic' to the journalists of the newspapers. One can only speculate as to what explains the difference in attitude between the Netherlands and Flanders in this issue; but as has been argued in section 2 above and in Van Oostendorp (2007), the difference may be mainly due to some accidental facts concerning media politics. In any case, it is clear that the spelling reforms caused a lot of irritation among people in both countries, and probably did harm to the DLU's reputation.

The DLU reacted in various ways. Some members of the spelling committee wrote furious reactions claiming that the critics were ignoramuses; one instance of this is Verkuyl (2005), who also made an interesting extra claim: in 1995, politicians had had a large influence on the spelling reform ("I will not discuss the role they had; that is for historians to find out.") whereas in 2005 the linguists had been enjoying more freedom. The General Secretariat reacted by publishing various press reports, a website with a piece of software that would give a respelling into the new orthography of texts written in the old one (the main goal of this was to show that the changes were only minimal), ${ }^{30}$ and a brochure (Nederlandse Taalunie 2006a).

All in all, it is fair to say that spelling is the topic of corpus planning policy which raises the most interest. The issue is hardly interesting for linguists, but still it has had relatively big implications both for the public image of these linguists and for the DLU.

\section{Official policy: status}

We now turn our attention to the status planning policies of the DLU. Here, we distinguish between (1) the position of the Dutch language in the international arena, specifically within the EU; (2) the position of minority languages within the Dutch speaking area; (3) activities to raise public awareness of linguistic issues. As in section 3, these topics have been roughly ordered with respect to the amount of public interest they raise, although it should be mentioned that none of the status planning activities has ever been able to raise the level of emotions to such an extent as the spelling issue.

\subsection{International position of Dutch}

Different from some other regions, the Dutch speaking area has never been very active in promoting its language abroad. For instance, although the Dutch colonial presence in

29Taalkundigen zijn de wiskundigen van de taal. Kom bij deze mathematische taalwetenschappers niet om liefde voor het woordbeeld of fascinatie voor de etymologie (afkomst van een woord). Taal moet vernieuwen, spelling moet vernieuwen: en dat allemaal in dienst van de gewenste eenvormigheid.

30 http:/ / woordenlijst.org/omspeller/ 
Indonesia has been comparable in many respects to its British counterpart in India, this has not led to a prominent position of the Dutch language in Indonesian society (Groeneboer 1997, 1998, who also explains why the situation was different in Surinam).

Also at present, the Dutch and Flemish governments are not very active in the international arena outside of the own language speaking area, and the activities of the DLU within for instance the European Union is severely limited. The emphasis is on participation in EFNIL, the European Federation of National Institutes for Language, which was established in 2003. The main goal of EFNIL is the preservation of linguistic diversity in Europe 'as a means of preserving and extending the richness of European culture and developing a sense of shared European identity', to support 'the European national languages as the best guarantors of linguistic opportunity within their respective member states' and to 'to support the European language organisations [...]'. Note that linguistic diversity within the member states - or at least diversity concerning non-standard languages - is very explicitly not a goal of the organisation, which seems to conform very well to official EU policies on this issue. By subscribing to EFNIL, DLU has explicitly agreed to be an organisation in favour of the national language (cf. section 4.2). Similar conclusions can be drawn from the 2005 `Brussels Declaration on Language Learning ${ }^{\prime 31}$, which seems to be the most important document of EFNIL so far and which was signed when the DLU organised the yearly EFNIL conference. Most of this is in line with a report of the DLU's Dutch Language and Literature Council (Smeets 2001), in particular with the more modest goals of this report, which are to stick to the official status quo within most European institutions and promote the official use of all standard languages. Some of the more radical recommendations of the Council - such as the one to also respect the rights of those people who speak a language which does not have an official status within the EU, have not been implemented by the Secretariat General so far. The most important activity concerning the promotion of the Dutch language in the outside world, however, concerns traditionally language education. The DLU financially supports foreign universities that offer a Dutch programme - in many cases as part of a Germanic linguistics or a German language program. There are 200 such programmes worldwide, but the amount of financial support varies according to the size of the programme, the numbers of students, the average income of university teachers, etc. ${ }^{32}$

Next to this, the DLU also developed several tools for teachers of Dutch as a foreign language, both in university and outside (for instance in German schools close to the borders). Many of these activities are coordinated at the Steunpunt Nederlands als vreemde taal ('Centre for Dutch as a Foreign Language') at the University of Amsterdam. This Centre has a website which provides information for teachers, ${ }^{33}$ for instance about the Certificaat Nederlands als Vreemde Taal ('Certificate Dutch as a Foreign Language'), an officially recognized document for successful students of the language. Finally, the DLU also finances summer courses for both students and teachers.

We can conclude from this that most of the activities concerning the promotion of Dutch concerns its academic use: learning the language and studying it at university. Very few acticities concern e.g. its active promotion in international institutions or other activities similar to e.g. the German Goethe Institute. European activities are not very high on the agenda of most people who are occupied with issues of language policy in the Dutch Language Area.

\subsection{Minority languages}

We have already noted an important political difference between the Netherlands and Belgium with respect to language policy in section 2: the former country has signed the

31 http://www.eurfedling.org/brusdec/genbrudec.htm

$32 \mathrm{http}: / /$ taalunieversum.org/taalunie/subsidiesystematiek_buitenlandse_neerlandistiek/

33 http://www.snvt.hum.uva.nl/ 
European Charter for Regional Languages or Languages of Minorities, whereas the latter has not.

The applicability of the Charter in the Netherlands is a complicated issue. Every state signing the Charter can make its own decisions as to which minority languages are considered applicable. In 1993, the plan of the Dutch government was to apply it only to Frisian, a West Germanic minority language spoken by approximately 350,000 speakers in the North, for which some official measures had already been taken in the 1950s.

However, in 1995, a group of speakers of so called Low Saxon dialects - also spoken in the North of the Netherlands, and closely related to Low German, which had been recognized by the German government as taking part of the Charter - mentioned to get a minor recognition. Something similar happened to Limburgian, a group of dialects spoken in the South-West, in 1997, and to Yiddish, Sinti and Roma in 1998. A 'minor' recognition means that the state formally recognizes the status of a variety as a separate language without taking the relevant measures. So far, Frisian is the only language which has received 'full' recognition. ${ }^{34}$ Until the turn of the century, the DLU has not been involved in any of the discussions regarding the Charter, presumably because these did not concern the Dutch standard language, and because the Charter had not been signed by Belgium, making this a less likely issue for DLU policy.

These things changed, however, when in 1999 the Belgian province of Limburg neighbouring the Dutch province of the same name, and home to a number of dialects which are very closely related to those on the Dutch side of the border - turned itself to the Flemish government, asking their opinion about a possible recognition by the Belgian state of Limburgian as a minority language. The Flemish government forwarded this request to the DLU, and the Secretary General, Koen Jaspaert, wrote a negative advice ${ }^{35}$, giving as a reason that "all scholarly literature, both from a synchronic and from a diachronic point of view, has always seen Limburgian as a dialect of Dutch and never as a separate language". ${ }^{36} \mathrm{He}$ also pointed out that the recognition of Low Saxon and Limburgian by the Dutch state "may have consequences for the status and the use of Dutch, because speakers of recognized regional languages cannot be counted as native speakers of Dutch ${ }^{\prime \prime 37}$, an argument based on the idea that monolingualism would be the norm, as well as on the idea that it is important to promote (Standard) Dutch in international (European) bodies who operate on the apparent assumption of monolingualism. Finally, he noted that "This opinion changes nothing to the fact that dialects, and in particular speakers of dialects have rights, and with respect to them one can still choose a policy of tolerance, protection and active support. The present advice consequently does not imply a disparagement of Limburgian or other dialects"138

34One could imagine that the interest for regional languages partly is inspired by international developments such as the instalment of a European Union. In the fis t place, 'regionalism' is sometimes seen as a natural reaction to internationalisation, for instance because international developments create uncertainty with respect to the individual's identity, who reacts to this by withdrawing to the identity provided by a smaller region (Lash and Urry 1994, Voicy and O'Riordan 2001, Simon 2005). At the same time, the developments are clearly also advanced by people looking across national borders: the movement in favour of Low Saxon was inspired by developments in Germany concerning Low German, and the Flemish request to the DLU concerning Limburgian was inspired by the developments in the Netherlands.

$35 \mathrm{http}: / /$ taalunieversum.org/taalunie/erkenning_van_het_limburgs/

36 "aangezien in alle wetenschappelijke literatuur, zowel diachrone als synchrone, het Limburgs altijd

beschouwd is als een dialect van het Nederlands en niet als een afzonderlijke taal".

37 "gevolgen kan hebben voor de status en het gebruik van het Nederlands, aangezien sprekers van erkende streektalen niet beschouwd kunnen worden als moedertaalsprekers van het Nederlands"

$38^{\prime \prime}$ Dit oordeel laat overigens onverlet dat ook dialecten en met name dialectsprekers rechten hebben en het 
It is interesting, unexpected and - as far as I can see - unprecedented that the Secretary General of the DLU made an explicit political statement like this, even criticizing the policies of one of the member states. It did not remain without effect either: in response to questions asked in Dutch parliament, the Dutch Minister of Interior Affairs promised that in future cases, the DLU would be consulted.

Such a case arose almost a year later, in 2000, when the Dutch province of Zeeland asked for recognition of Zeeuws. The Council gave a negative advice in $2001^{39}$, providing as its only argument that Zeeuws is a dialect of Dutch, not a separate language. Their main source for this was a textbook by the renowned Dutch dialectologist Goossens (1977), who defined Dutch dialects as "dialects which are related to Dutch and which are spoken in an area in which Dutch, and no more closely related language, plays the role of standard language" ${ }^{40}$ The Council points out that in this view Low Saxon and Limburgian should not have been recognized either; it does not really answer the question why the situation is different for Frisian, which is also related to Dutch (since both languages are West Germanic) and spoken in an area (the Netherlands) as the official language. One could answer that Frisian has some official rights and therefore partly plays the role of a standard language as well, but this makes the argument circular, since most of these rights are now covered by the Charter. Therefore, Frisian can be recognized because it is recognized, and others cannot be recognized, because they are not.

At the end of their advice, the Council pointed out that they do not intend to "disparage" dialects or other varieties of Dutch. They point out that in another advice (Smeets 2001) asks among other things for more 'protection' of regional language (see section 4.1.). This part of the policy has not been implemented at present.

All in all, it seems fair to say, therefore, that the DLU has been a negative force in the application of European policies as to the protection of regional varieties - it is of course a political question whether such a policy is necessar. We may also observe that the organisation has played a role which might be expected from an organisation involved in the promotion of a standard language.

It should also be noted that in this particular case it is not so clear that the DLU had to operate within a field in which linguistic specialists have different interests or concerns than laymen. Among both groups both proponents and opponents of recognition of, e.g., Zeeuws can be found.

\subsection{Public awareness}

We have seen so far that on several occasions, the DLU has become the centre of public debate. It has also sought the public debate itself, and has done so in various ways. Until approximately 2000, a paper magazine appeared called Taalschrift ('Language Cahier'); this was turned into a website in $2003 .{ }^{41}$ Both the paper magazine and the website feature background articles on language policy issues, written in a journalistic style. The website also invites authors every month to write slightly provocative articles on issues such as 'We cannot force people to speak Dutch on the street' (February 2006) or 'We should introduce linguistics

beleid ook te dien aanzien kan kiezen voor tolerantie, bescherming en actieve ondersteuning. Het voorliggende advies houdt derhalve geen depreciatie in voor de Limburgs of andere dialecten [...]."

39 http:/ / taalunieversum.org/taalunie/advies_inzake_de_erkenning_van_het_zeeuws_als_regionale_taal/ind ex.php\#III

40 'Nederlandse dialecten zijn met het Nederlands verwante dialecten die gesproken worden in het gebied waar het Nederlands, en geen enger verwante taal, de rol van cultuurtaal vervult.'

41 http://taalschrift.org/ 
in schools' (September 2005). The number of responses by visitors varies; in February 2007, the least popular one had 7 replies (February 2004); the most popular one 360 (January 2006). This indicates that the audience is rather small and possibly restricted to a group of people who have a professional interest in language. Nederlandse Taalunie (2006b) claims that the number of subscribers to an e-mail alert of Taalschrift was 1,650.

It is also interesting to see that very few of the discussions involved international status planning or the position of Dutch within the EU: as of February 2007, 3 out of 39 discussions (i.e. 8\%) touched on this topic. Two of the opinion articles opening these discussions were written by Jan Roukens, a formal civil servant for the European Union, and one by Rieks Smeets, a linguist who currently works for Unesco.

Taalunieversum ('Language universe', and a pun on the Dutch name of the DLU), the central website of the DLU enjoys more popularity. According to Nederlandse Taalunie (2006b), the number of visitors to this website was 2,740,000 in 2005, which would equal 7,507 a day, except that it is not clear how many of these are unique visitors. In any case, Taalunieversum contains an overwhelming amount of information, in particular for the specialist: every publication of the DLU since 2000 has appeared online. Furthermore, the website contains the complete texts of the Word List, the database with language advice, a (somewhat random) collection of links to language resources on other websites, etc. Furthermore, also the topics not covered in this article (language education in the Netherlands and Flanders, and literature) get a lot of attention on this website, although also in this case the target audience mainly seem to be specialists and people working in the field. Again, there is very little serious attention for the position of Dutch within the EU, reflecting the general lack of interest for these topics.

In 2005 and 2006, the DLU published a glossy magazine. Taalpeil (Language Level), presenting a survey study among speakers of Dutch about their general views on language in 2005 and about their reading habits in 2006. So far, the DLU had not very explicitly engaged itself with the latter topic, but in the introduction, Secretary General Linde van den Bosch notes "the DLU considers it to be its task to make sure that whoever knows or learns Dutch, can use the language in an optimal way. Reading is a special form of language use; some people can spend hours on it attentively. But exactly this attentive reading looses terrain. How bad is that?" 42

It is not clear how many copies of Taalpeil reached the general public for which it was targeted, and in general the audience of DLU publications seem rather small. The journal Onze Taal of the association with the same name at the same time reached an audience of about 40,000 people.

\section{Conclusion: The DLU, experts and politicians}

In this article, we have seen that the DLU is engaged in a number of activities concerning language planning. Virtually every corpus activity which might be expected for a language of the size and status of Standard Dutch, is performed by the DLU. In the first place, this concerns corpus planning activities - both of a traditional nature (subsidizing dictionaries, giving advice on correct use) and of a more modern nature (subsidizing projects on electronic use) - and status planning activities - both in the international arena and at home. In 2003, the DLU chose as its motto 'De taalgebruiker centraal' (The language user central). This reflects the internal focus of most language planning activities within the Dutch speaking area: one is concerned with the language user within the Dutch speaking area, and not so much with the position of Dutch internationally, for instance within an expanding Europe.

$42^{`}$ De Nederlandse Taalunie ziet het als haar taak ervoor te zorgen dat wie Nederlands kent of leert, die taal zo goed mogelijk kan gebruiken. Lezen is een heel speciale vorm van taalgebruik; sommige mensen kunnen er uren aandachtig mee bezig zijn. Maar juist dat aandachtige lezen verliest terrein. Is dat zo erg?' 
The question arises to what extent DLU is reaching its target audience: the 'average language user'. We have seen above that in many cases, it is first and foremost experts - historical scholars, specialists in speech technology - who profit from the work of the DLU directly. However, one might argue that since the financial support allows these people to work, eventually also the general public will profit from this.

Yet we have also seen that the DLU explicitly tries to engage a more general audience in its activities, but that at certain crucial points it failed to do that; and in some cases it became the target of criticisms. The critics in those cases seemed to view the DLU as a group of unworldly scholars.

One reason for this may have been the fact that the Secretary General of the DLU indeed always was a specialist, and during a certain time even a scholar; and furthermore, this Secretary General in many cases acts as the public face of the DLU. It is often the Secretary General who talks to the press or writes newspaper articles such as Jaspaert (2003) or introductions such as Linde van den Bosch in Taalpeil (cf. section 4.3). In some cases, such as the decision procedure on the recognition of Zeeuws as a regional language, the Secretary General seemed to have assumed an important role in the decision procedure, writing to a Flemish official in his own name, and providing arguments which would later be adapted by the Council.

This importance of a high official is different in other domains of public policy: a high official in a certain ministry is not (always) necessarily an expert in the relevant domain; and more importantly, usually it is the person who is politically responsible - i.e. the minister or some other elected person - who will defend the decisions which have been made. One could argue that this is how it should be, and furthermore, that this also makes the issues involved more accessible to a non-specialist audience.

We have also seen in section 2 that the DLU is monitored by an 'Interparliamentary Committee' of parliamentarians. This means that language issues are hardly ever a topic of discussion in the 'real' parliaments of the Netherlands and Flanders. This means that language policy issues are depoliticized and seem to be more an issue of specialized interest than of public debate. It is interesting that in this respect, DLU is like a small version of the European Union: internationalisation obscures the democratic process, and makes it more difficult for the voter to see what is going on, let alone influence this process directly. At the same time, several language-related issues have been the topic of heated debate both in the Netherlands and in Flanders; most prominently, perhaps, a debate on the desired language proficiency skills of immigrants. In such cases, the voice of experts is not heard very often. Bridging the gap between experts and politicians remains a very difficult task indeed. Most interestingly however, in the context of the current issue of Sociolinguistica, is the fact that international policies have been next to invisible in all debates concerning language planning in the Netherlands and Flanders in the period of time discussed here. While the EU expanded, and Dutch logically lost terrain in international institutions, public debate concentrated mostly on spelling and the position of regional languages. There are several possible (and converging) reasons for this. First, as already pointed out in the introduction and section 4.2 , this may reflect a more general trend in public interest away from international matters towards smaller, national or even regional, interests. At the same time, also experts and specialists within the Dutch speaking area seem more involved with issues of corpus planning, which are inherently less international in scope. Finally, experts and the general public may share the feeling that international language issues are very hard to influence; at least more so than the position of Zeeuws, or the rules concerning orthography.

\section{References}

Beheydt, Ludo. 1997. Talengebruik in de internationale context. Een kwestie van democratie? 
in: G. van den Bergh (e.a.), Over de toekomst van het Nederlands.

Cobarrubias, J., and J.A. Fishman (eds). 1983. Progress in Language Planning. International Perspectives. Berlin: Mouton.

Daelemans, Walter, and Helmer Strik (eds.) 2002. Het Nederlands in taal- en

spraaktechnologie. Prioriteiten voor basisvoorzieningen. Een rapport in opdracht van de Nederlandse Taalunie. Unpublished.

http: / / taalunieversum.org/taal/technologie/ docs/ daelemans-strik.pdf

De Caluwe, Johan; Dirk Geeraerts; Sjaak Kroon; Virginie Mamadouh; Ronald Soetaert; Luc

Top and Ton Vallen (eds.) 2002. Taalvariatie E taalbeleid. Bijdragen aan het taalbeleid in

Nederland en Vlaanderen. Antwerpen-Apeldoorn: Garant. ]

Evaluatiecommissie. 2004. Zorg voor de taal. Evaluatie van de Nederlandse Taalunie. Advies aan het Comité van Ministers. Den Haag: Nederlandse Taalunie.

Goossens, Jan. 1977. Inleiding tot de Nederlandse dialectologie. Groningen: Wolters-Noordhoff.

Govaert, S. 1982. La Flandre et les Pays-Bas. Courrier hebdomadaire du CRISP, nr. 960-961

Groeneboer, Kees. 1997. 'De toekomst van het Nederlands'. Tydskrif vir Nederlands $\mathcal{E}$ Afrikaans, 4, 1. URL http:/ / academic.sun.ac.za/ afrndl/tna/groeneboer97.html.

1998. 'Westerse koloniale taalpolitiek in Azië. Het Nederlands, Portugees, Spaans, Engels en Frans in vergelijkend perspectief '. Mededelingen van de Afdeling Letterkunde, Nieuwe Reeks., 61, 2.

Haugen, Einar. 1990. Babels forbrødring. Om tospråklighet og språkplanlegging. (Oversatt av Dag Gundersen. Det Blå Bibliotek.) Oslo: Universitetsforlaget

Horst, Joop van der. 1999. Van WNT en ANS tot Poldernederlands. Kroniek van de taalkunde. Neerlandica Extra Muros 37.1: 47-52.

Jaspaert, Koen. 1986. Statuut en structuur van standaardtalig Vlaanderen. Leuven: Universitaire Pers Leuven.

Kloss, H. 1969. Research Possibilities on Group Bilingualism. A Report. Québec: Université Laval, CIRB \#28.

Lash, S., and J. Urry. 1994. Economies of Sign and Space. London: Sage.

Leerssen, Joep \& Anton Heumakers. 2002. 'Streektaal en erkenning: een paradox en zes misverstanden'. In: Mathijsen, M. (ed.), Hartstocht in contrapunt. Amsterdam: Bezige Bij.

Milroy, J. (2001). Language ideologies and the consequences of standardization. Journal of Sociolinguistics 5, 4, 530-555.

Nederlandse Taalunie. 2003. De taalgebruiker centraal. Meerjarenplan 2003-2007. Den Haag: Nederlandse Taalunie.

Nederlandse Taalunie. 2006a. Verandert de spelling alweer? Wat u moet weten over de spellingaanpassing. Den Haag: Nederlandse Taalunie. http: / / taalunieversum.org/spelling/voorlichting/

Nederlandse Taalunie 2006b. De Taalunie in 2005 en 2006. Een tussenbalans. Den Haag: Nederlandse Taalunie.

Oostendorp, M. van. 2007. Meningen over taal. Frankrijk, België en Nederland. Manuscript, Meertens Instituut

Rietveld, Toni, and Ingeborg Solte. 2005. Taal- en spraaktechnologie en communicatieve beperkingen. Den Haag: Nederlandse Taalunie.

Simon, Carola. 2005. Ruimte voor identiteit. De productie en reproductie van streekidentiteiten in Nederland. PhD Dissertation, Groningen University.

Smakman, Dick. 2006. Standard Dutch in the Netherlands. A sociolinguistic and phonetic description. Utrecht: LOT Publications.

Smeets, Rieks. 2001. Naar een samenhangend taalbeleid voor het Nederlands vanuit Europees perspectief. Unpublished report, Leiden University. http: / / taalunieversum.org/taalunie/advies_inzake_taalbeleid_in_europees_perspecti 
ef/01rntleuropa_rapport.pdf

Velde, Hans Van de. 1996. Variatie en verandering in het gesproken Standaard-Nederlands. PhD Dissertation, Nijmegen University.

Voisy, H., and R. O'Riorsan. 2001. Globalization and localization. In: T. O'Riordan (ed.) Globalism, Localism and Identity. Fresh Perspectives on the Transition to Sustainability. London and Sterling: Earthscan, p. 25-42.

Willemyns, R. 1984a. Le Traité de l'union de la langue néerlandaise : Une expérience unique dans les relations internationales linguistiques. La Linguistique 20, 81-96.

Willemyns, R. 1984b. A Common Legal Framework for Language Unity in the Dutch Language Area : The Treaty of Linguistic Union. Multilingua 3-4, 215-223.

Willemyns, R. 1990. Taalplanning door de Nederlandse taalunie. In Publikatieblad Nederlandse Taalunie 3, \# 2, 25-29.

Willemyns, R. 1987. Dutch in the European Union: The Language Policy of the "Nederlandse Taalunie". Sociolinguistica XI, 53-62.

Wilterdink, Nico. 2004. Van apenkool tot zielenpoot. Amsterdams Sociologisch Tijdschrift, 2: 31, Amsterdam

\section{Newspaper articles}

Jaspaert, Koen. 2003. Taal blijkt in heel beperkte mate maakbaar. De Volkskrant 23.10.2003, p. 7. Rijckevorssel, René van. 2005. Terreur der taalgoden. Elsevier 14.10.2005.

Sanders, Ewoud. 2005. Spellingoorlog. NRC Handelsblad 19.12.2005, p. 18.

Verkuyl, Henk. 2005. Woede over spelling is onterecht. De Volkskrant 24.12.2005. 